\title{
Prevalence and Risk Factors of Asthma in School Going Children in South India
}

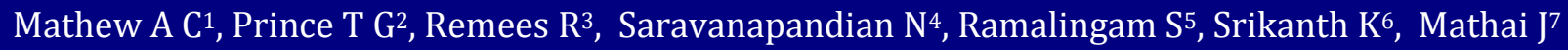

1Professor of Biostatistics, Department of Community Medicine, P S G Institute of Medical Sciences and Research, Coimbatore, Tamilnadu, India.

${ }^{2}$ Trainee Biostatistician, Department of Statistical Sciences, Kannur University, Kannur, Kerala, India.

${ }^{3}$ Trainee Biostatistician, Department of Statistics, St. Thomas College, Pala, Kerala. , India.

${ }^{4}$ Assistant Professor, Department of Pediatrics, P S G Institute of Medical Sciences and Research, Coimbatore, Tamilnadu, India.

${ }^{5}$ Assistant Professor, Department of Community Medicine, P S G Institute of Medical Sciences and Research, Coimbatore, Tamilnadu, India.

${ }^{6}$ Professor \& HOD, Department of Tuberculosis and Chest diseases, P S G Institute of Medical Sciences and Research, Coimbatore, Tamilnadu, India.

${ }^{7}$ Professor \& HOD, Department of Pediatrics, P S G Institute of Medical Sciences and Research, Coimbatore, Tamilnadu, India.

\section{Original Article}

\section{Corresponding Author:}

Dr. Anil C Mathew PhD

Professor of Biostatistics

Department of Community Medicine

P S G Institute of Medical Sciences and Research,

Coimbatore, Tamilnadu, India.

E-mail: anilpsgmet@gmail.com

\section{Abstract}

\section{Background}

In India, the prevalence of asthma has increased over the last two decades especially in children and young adults. The aim of the study was to estimate the prevalence of asthma in school going children aged $5-10$ and $11-15$ years in the city of Coimbatore and determine the risk factors associated with it.

\section{Materials and methods}

A school based cross-sectional study was conducted at the urban field practice area of PSGIMSR, Coimbatore between 1st June 2011 and 31st August 2011. The questionnaire was filled by the parents and collected from the children. The data were analyzed using SPSS (11.5version).

\section{Results}

The prevalence of asthma among children aged 5-10 years was 9.5\% (95\% Confidence Interval (Cl) $7.49-11.50)$ and among children aged $11-15$ years was $7.27 \%$ (95\% Cl $5.40-$ 9.14). The Risk factors significantly associated with asthma among children aged 5-10 years were positive family history of asthma (Odds Ratio (OR)=3.10, 95\% Cl 1.80 - 5.36), longer duration of time spent in front of television and computer $(\mathrm{OR}=2.75,95 \% \mathrm{Cl} 1.44$ - 5.25), having food allergies (OR=2.36, 95\% Cl $1.19-4.68)$, and low birth weight of the child (OR=1.79, 95\% Cl 1.08 - 2.98). The factors significantly associated with asthma among children aged $11-15$ years were positive family history of asthma $(\mathrm{OR}=2.99,95 \% \mathrm{Cl}$ 1.34 - 6.64), poor ventilation ( $\mathrm{OR}=4.94,95 \% \mathrm{Cl} 2.72-8.93)$, and use of pillows made up of wool, foam or synthetic 
material (OR=2.7, 95\% Cl 1.31 - 5.58).

\section{Conclusion}

Our data suggests that there is a high prevalence of asthma among school going children in Coimbatore. Parental history of asthma was a risk factor in both age groups studied. Television viewing for more than 2 hours, low birth weight and food allergy are additional risk factors for children aged 5-10 years. Poor ventilation and use of pillows made up of wool/ foam/ synthetic material are other risk factors in 1115 years old children. Appropriate preventive strategies may help reduce the risk of asthma. Children with low birth weight and a family history of asthma need careful evaluation and long term follow up.

\section{Keywords}

Asthma, Prevalence, Television watching, Food allergy, Low birth weight, Parental asthma

\section{Background}

Asthma is a common chronic disease which causes considerable mortality and morbidity in children. In the last two decades, a significant increase in the prevalence of asthma has been reported from different parts of the world, with figures ranging from $1 \%$ to $20 \%{ }^{1}$. At a global level, studies have reported one year prevalence rates ranging from 4.1 to $32.1 \%$, with Australia, Brazil and Costa Rica showing the highest rates while South East Asian countries like India, Indonesia and Malaysia had relatively low rates ${ }^{2}$. In some parts of India, the prevalence of asthma has increased very dramatically over the last two decades ${ }^{3}$. There is also a wide variation (4\% to $19 \%$ ) in the prevalence of asthma in school going children reported from different geographical areas of India ${ }^{4}$. While in Bangalore it was $29.5 \%$, the prevalence of diagnosed asthma in Tamil Nadu was only $5 \%$, . Hence prevalence data from many more regions of India are needed.

Many different risk factors responsible for asthma such as food habits, physical activity, family history of asthma, parental education, birth weight of the child and socio economic factors have been identified by various researchers. Environmental factors such as atmospheric pollution as well as life style changes have been implicated in various ways for the increasing frequency of childhood allergic diseases ${ }^{7,8}$. This leads to the conclusion that regional risk factors need to be identified in order to have efficient preventive strategies for allergic diseases. The study aims to determine the prevalence of asthma as well as the triggers and risk factors of asthma among children of two age groups (5-10 years and $11-15$ years) in Coimbatore.

\section{Material and Methods}

\section{Data collection}

This study was conducted at the urban field practice area schools of the department of Community medicine, PSGIMS\&R, Coimbatore between June 1, 2011 and 31 August 2011. Both the questionnaire and parent consent form were prepared in English and the local language (Tamil) and distributed to children after explaining all the questions. Parents were requested to give consent and fill the questionnaire personally. Parents were asked to contact the authors in case of any doubts. The forms were collected back from the children over the subsequent two days.

\section{Sample size calculation}

For $95 \%$ confidence interval and significance level $\alpha=5 \%$, $\mathrm{P}=10 \%, \mathrm{Q}=90 \%$, allowable error $=3 \%$, expected non response $=20 \%$, the required sample size was 500 for each age group where $\mathrm{P}=$ prevalence reported in earlier studies.

\section{Sampling methods, inclusion and exclusion criteria}

From the listed twelve schools in the field practice area of urban health centre of PSGIMS\&R, six schools (i.e. 3 aided, 2 private, 1 corporation school) were selected. After obtaining consent from school authorities and corporation education department, all children in eligible ages were invited for participation. The questionnaire included the validated ISAAC screening questions and some other questions related to risk factors of asthma. Total of 1800 students were thus selected from the six schools and the questionnaires were distributed to all of them. Among them, parents of 1620 children were responded. From these, 58 students were excluded based on the exclusion criterion (children with heart disease, emphysema, kidney disorder and chronic bronchitis). Of the remaining 1562 students, 820 ( 589 girls and 231 boys) were in the age group of 5-10 years, and 742 (513 girls and 229 boys) were in the age group of 11-15 years.

\section{Outcome variable}

The primary outcome of the study is the estimation of the prevalence of asthma. If any of the answer to the ISAAC questions were "yes", the child was identified as a case of asthma.

\section{Explanatory variables}

The explanatory variables included in the study were demographic characteristics, environmental exposure, breastfeeding, food pattern, lifestyle, birth weight, food allergy, and family history. Family history was defined as the presence of asthma in any of the parent, siblings or secondary relation. Environmental factors considered were 
exposure of child to kitchen smoke, passive smoking, ventilation in the house, exposure to pets and presence of industry beside their house. Lifestyle factors included were time spent on television and computer (in hours) and average time of play or exercise (in hours) daily. Information related to total duration of breast feeding (in months) was also elicited.

\section{Ethical committee approval}

Approval was taken from the institutional ethics committee prior to the study.

\section{Data management and statistical analysis}

The data collected were analyzed using SPSS (11.5 version). For each group, prevalence of asthma and its 95\% confidence interval was calculated. Crude odds ratio (OR) with $95 \%$ confidence interval was calculated to assess association of individual risk factors with asthma using logistic regression analysis. Those variables significant at univariate analysis at $p<0.05$ were considered for multivariate analysis. Normal birth weight was taken as 2.7 $4.0 \mathrm{~kg}$. We measured the Socioeconomic status (SES) based on Prasad's modified classification which was based on Annual consumer price index (Industrial work) (ACPI (IW)) for the month of May 2011 after rounding off to the nearest Rs. $10^{9}$. For those per capita monthly income more than Rs 2130 were considered as upper class (class I and Class II) and less than Rs 2130 were considered as low class (class III, class IV and class V). Children fed up 12 months (median duration of breastfeeding) or more were compared with children fed up less than 12 months.

\section{Results}

\section{Prevalence of asthma}

The prevalence of asthma among children aged 5-10 years was $9.5 \%(95 \% \mathrm{Cl} 7.49-11.50)$ and among children aged $11-15$ years was $7.27 \%(95 \% \mathrm{Cl} 5.40-9.14)$.

\section{Factors associated with asthma in children $5-10$ years}

Table 1 and 2 shows the factors significantly associated with asthma among children aged 5-10 years. The positive family history of asthma (OR=3.10, 95\% Cl $1.80-5.36)$, more hours of television and computer viewing $(\mathrm{OR}=2.75,95 \% \mathrm{Cl} 1.44$ $5.25)$, having food allergy (OR=2.36, 95\% Cl $1.19-4.68)$, and low birth weight of the child (OR=1.79, 95\% Cl 1.08 - 2.98) were significantly associated with asthma in children 5-10 years.
Table 1- Association of asthma and various risk factors in children aged $5-10$ years

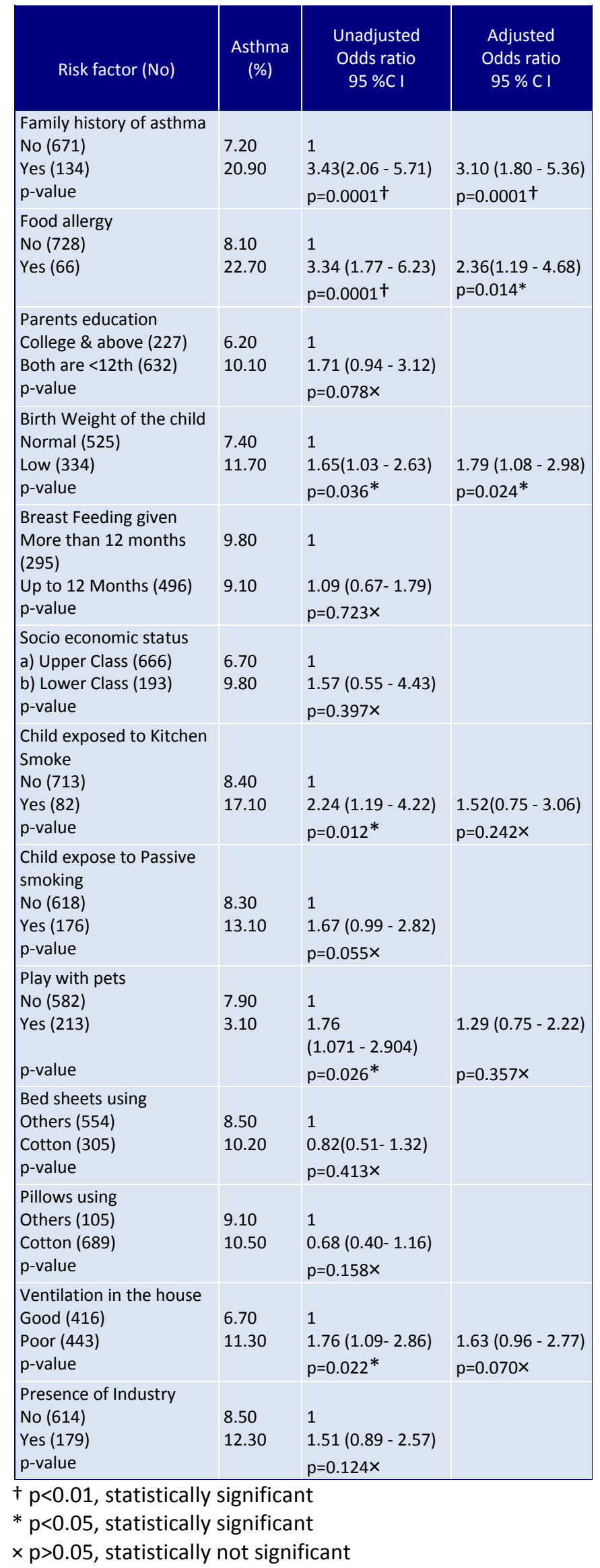


Table 2- Association of asthma and various risk factors in children aged $5-10$ years

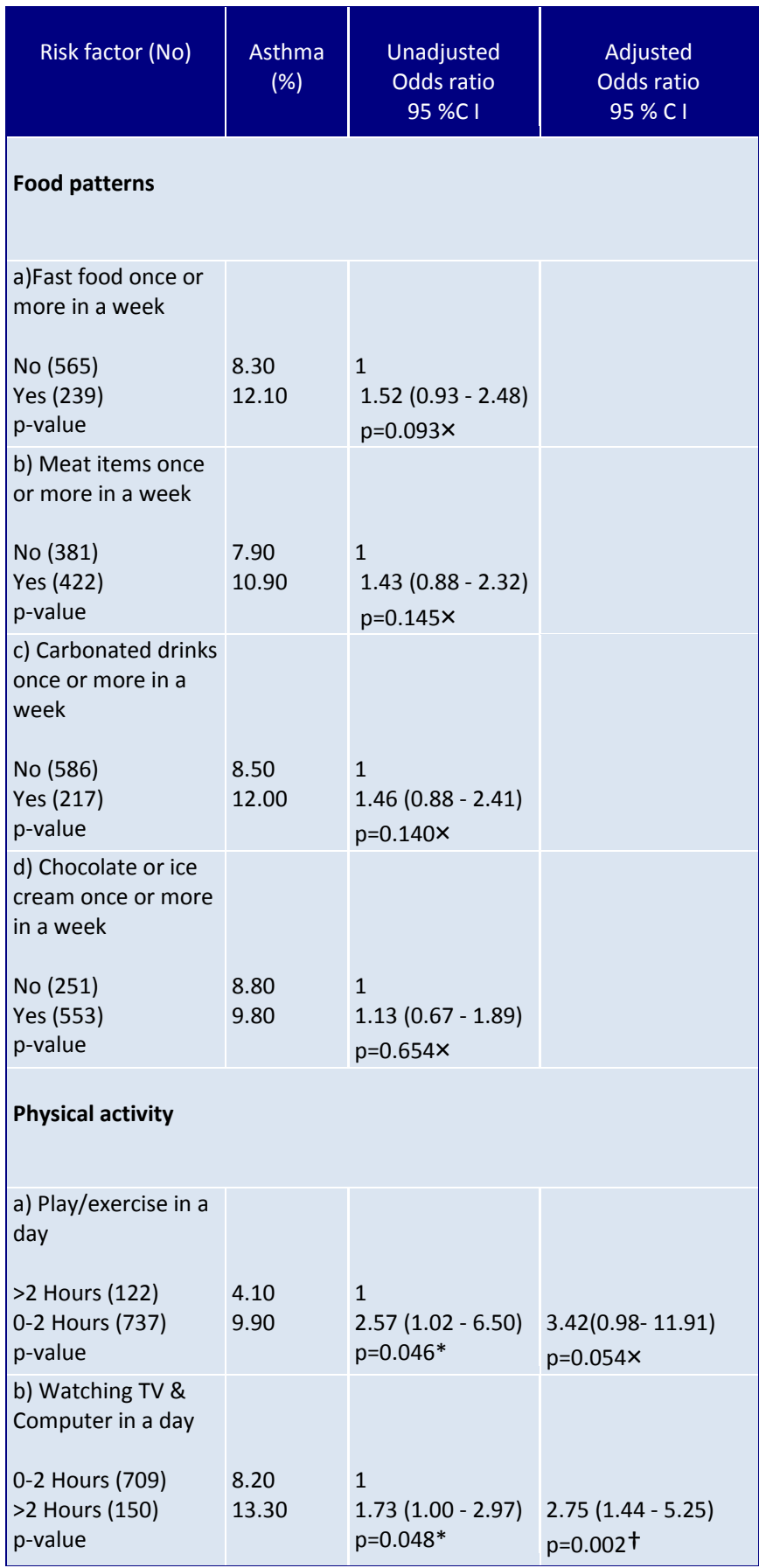

$+p<0.01$, statistically significant

$* p<0.05$, statistically significant

$\times p>0.05$, statistically not significant

\section{Factors associated with asthma in children $11-15$ years}

Table 3 and 4 presents the factors significantly associated with asthma among children aged 11-15 years. The factors significantly associated with asthma were positive family history of asthma (OR=2.99, $95 \% \mathrm{Cl} 1.34$ - 6.64), poor ventilation $(\mathrm{OR}=4.94,95 \% \mathrm{Cl} 2.72-8.93)$, and use of pillows made up of wool or foam or synthetic materials
(OR=2.7, 95\% Cl $1.31-5.58)$.

Table 3- Association of asthma and various Risk factors in children aged 11-15 years

\begin{tabular}{|c|c|c|c|}
\hline Risk factor (No) & $\begin{array}{c}\text { Asthma } \\
(\%)\end{array}$ & $\begin{array}{l}\text { Unadjusted } \\
\text { Odds ratio } \\
95 \% \mathrm{Cl}\end{array}$ & $\begin{array}{l}\text { Adjusted } \\
\text { Odds ratio } \\
95 \% \mathrm{Cl}\end{array}$ \\
\hline $\begin{array}{l}\text { Family history of asthma } \\
\text { No (674) } \\
\text { Yes (78) } \\
\text { p-value }\end{array}$ & $\begin{array}{l}5.50 \\
20.50\end{array}$ & $\begin{array}{l}1 \\
4.37(2.30 \quad 8.29) \\
p=0.001{ }^{\dagger}\end{array}$ & $\begin{array}{l}2.95(1.33-6.56) \\
P=0.008^{\dagger}\end{array}$ \\
\hline $\begin{array}{l}\text { Food allergy } \\
\text { No (694) } \\
\text { Yes (39) } \\
\text { p-value }\end{array}$ & $\begin{array}{l}5.8 \\
12.80\end{array}$ & $\begin{array}{l}1 \\
2.40(0.89-6.48) \\
P=0.08 \times\end{array}$ & \\
\hline $\begin{array}{l}\text { Parents education } \\
\text { College \& above (475) } \\
\text { Both are }<12 \text { th (279) } \\
\text { p-value }\end{array}$ & $\begin{array}{l}8.60 \\
6.30\end{array}$ & $\begin{array}{l}1 \\
0.71(0.41-1.25) \\
p=0.242 x\end{array}$ & \\
\hline $\begin{array}{l}\text { Birth Weight of the child } \\
\text { Normal (509) } \\
\text { Low (245) } \\
\text { p-value }\end{array}$ & $\begin{array}{l}5.70 \\
10.20\end{array}$ & $\begin{array}{l}1 \\
1.88(1.68-3.29) \\
p=0.02^{*}\end{array}$ & $\begin{array}{l}1.09(0.54-2.20) \\
p=0.81 x\end{array}$ \\
\hline $\begin{array}{l}\text { Breast Feeding given } \\
\text { More than } 12 \text { months } \\
\text { (241) } \\
\text { Up to } 12 \text { Months (469) } \\
\text { p-value }\end{array}$ & $\begin{array}{l}7.90 \\
5.30\end{array}$ & $\begin{array}{l}1 \\
0.66(0.36-1.22) \\
p=0.184 x\end{array}$ & \\
\hline $\begin{array}{l}\text { Socio economic status } \\
\text { a) Upper Class (426) } \\
\text { b) Lower Class (296) } \\
\text { p-value }\end{array}$ & $\begin{array}{l}7.00 \\
4.70\end{array}$ & $\begin{array}{l}1 \\
1.53(0.79-2.93) \\
p=0.20 x\end{array}$ & \\
\hline $\begin{array}{l}\text { Child exposed to Kitchen } \\
\text { Smoke } \\
\text { No (680) } \\
\text { Yes (53) } \\
\text { p-value }\end{array}$ & $\begin{array}{l}5.40 \\
15.10\end{array}$ & $\begin{array}{l}1 \\
3.69(1.36-7.03) \\
p=0.007 \dagger\end{array}$ & $\begin{array}{l}1.39(0.45-3.27) \\
p=0.70 x\end{array}$ \\
\hline $\begin{array}{l}\text { Child expose to Passive } \\
\text { smoking } \\
\text { No (632) } \\
\text { Yes (101) } \\
\text { p-value }\end{array}$ & $\begin{array}{l}5.70 \\
8.90\end{array}$ & $\begin{array}{l}1 \\
0.617(0.29-1.32) \\
p=0.21\end{array}$ & \\
\hline $\begin{array}{l}\text { Play with pets } \\
\text { No (564) } \\
\text { Yes (169) } \\
\text { p-value }\end{array}$ & $\begin{array}{l}6.20 \\
5.90\end{array}$ & $\begin{array}{l}1 \\
0.95(0.46-1.96) \\
p=0.891 \times\end{array}$ & \\
\hline $\begin{array}{l}\text { Bed sheets using } \\
\text { Cotton (497) } \\
\text { Others (257) } \\
\text { p-value }\end{array}$ & $\begin{array}{l}5.00 \\
11.30\end{array}$ & $\begin{array}{l}1 \\
0.42(0.24-0.73) \\
p=0.002 \dagger\end{array}$ & $\begin{array}{l}1.01(0.49-2.07) \\
p=0.96 \times\end{array}$ \\
\hline $\begin{array}{l}\text { Pillows using } \\
\text { Cotton (596) } \\
\text { Others (158) } \\
\text { p-value }\end{array}$ & $\begin{array}{l}4.70 \\
16.50\end{array}$ & $\begin{array}{l}1 \\
0.250(0.14-0.44) \\
p=0.001^{\dagger}\end{array}$ & $\begin{array}{l}0.37(0.181-0.789) \\
p=0.01^{*}\end{array}$ \\
\hline $\begin{array}{l}\text { Ventilation in the house } \\
\text { Good (416) } \\
\text { Poor (443) } \\
\text { p-value }\end{array}$ & $\begin{array}{l}5.10 \\
20.80\end{array}$ & $\begin{array}{l}1 \\
4.93(2.72-8.93) \\
p=0.001 \dagger\end{array}$ & $\begin{array}{l}3.22(1.48-7.0) \\
p=0.03^{*}\end{array}$ \\
\hline $\begin{array}{l}\text { Presence of Industry } \\
\text { No (614) } \\
\text { Yes (179) } \\
\text { p-value }\end{array}$ & $\begin{array}{l}5.40 \\
10.40\end{array}$ & $\begin{array}{l}1 \\
2.04(1.063 .94) \\
p=0.03^{*}\end{array}$ & $\begin{array}{l}1.31(0.605-2.84) \\
p=0.49 x\end{array}$ \\
\hline
\end{tabular}

$+p<0.01$, statistically significant

$* p<0.05$, statistically significant

$x p>0.05$, statistically not significant 
Table 4- Association of asthma and various Risk factors in children aged 11-15 years

\begin{tabular}{|c|c|c|c|}
\hline Risk factor (No) & $\begin{array}{l}\text { Asthma } \\
(\%)\end{array}$ & $\begin{array}{l}\text { Unadjusted } \\
\text { Odds ratio } \\
95 \% \mathrm{C} \mathrm{I}\end{array}$ & $\begin{array}{c}\text { Adjusted } \\
\text { Odds ratio } \\
95 \% \text { C I }\end{array}$ \\
\hline \multicolumn{4}{|l|}{ Food patterns } \\
\hline $\begin{array}{l}\text { a)Fast food once or } \\
\text { more in a week } \\
\text { No (565) } \\
\text { Yes (239) } \\
\text { p-value }\end{array}$ & $\begin{array}{l}4.50 \\
14.40\end{array}$ & $\begin{array}{l}1 \\
3.55(1.95-6.49) \\
p=0.0001 \dagger\end{array}$ & $\begin{array}{l}1.89(0.90-3.96) \\
p=0.98 x\end{array}$ \\
\hline $\begin{array}{l}\text { b) Meat items once } \\
\text { or more in a week } \\
\text { No ( } 414) \\
\text { Yes ( } 329) \\
\text { p-value }\end{array}$ & $\begin{array}{l}7.90 \\
10.90\end{array}$ & $\begin{array}{l}1 \\
1.28(0.71-2.29) \\
p=0.41 \times\end{array}$ & \\
\hline $\begin{array}{l}\text { c) Carbonated drinks } \\
\text { once or more in a } \\
\text { week } \\
\text { No (625) } \\
\text { Yes (216) } \\
\text { p-value }\end{array}$ & $\begin{array}{l}5.0 \\
13.80\end{array}$ & $\begin{array}{l}1 \\
3.23(1.721-6.04) \\
p=0.001 \dagger\end{array}$ & $\begin{array}{l}1.82(0.84-3.97) \\
P=0.12 x\end{array}$ \\
\hline $\begin{array}{l}\text { d) Chocolate or ice } \\
\text { cream once or more } \\
\text { in a week } \\
\text { No (321) } \\
\text { Yes (423) } \\
\text { p-value }\end{array}$ & $\begin{array}{l}3.40 \\
8.70\end{array}$ & $\begin{array}{l}1 \\
2.70(1.35-5.37) \\
p=0.005 \dagger\end{array}$ & $\begin{array}{l}1.79(0.79-4.03) \\
P=0.17 x\end{array}$ \\
\hline Physical activity & & & \\
\hline $\begin{array}{l}\text { a) Play/exercise in a } \\
\text { day } \\
>2 \text { Hours }(44) \\
0-2 \text { Hours }(700) \\
\text { p-value }\end{array}$ & $\begin{array}{l}9.10 \\
6.30\end{array}$ & $\begin{array}{l}1 \\
0.67(0.230-1.96) \\
p=0.46 x\end{array}$ & \\
\hline $\begin{array}{l}\text { b) Watching TV \& } \\
\text { Computer in a day } \\
0-2 \text { Hours ( } 621 \text { ) } \\
>2 \text { Hours (121) } \\
\text { p-value }\end{array}$ & $\begin{array}{l}5.80 \\
9.90\end{array}$ & $\begin{array}{l}1 \\
0.56(0.29-1.11) \\
p=0.09 x\end{array}$ & \\
\hline
\end{tabular}

$+p<0.01$, statistically significant

$* p<0.05$, statistically significant

$\times p>0.05$, statistically not significant

\section{Discussion}

In this study, the prevalence of asthma in children aged 5-10 years was $9.5 \%$ and in children $11-15$ years was $7.27 \%$. There are three studies already published from South India. Data from Kerala during the ISSAC study reported a prevalence of $3.7 \%$ in $6-7$ year old and $4.5 \%$ in $13-14 \mathrm{yr}$ old and children ${ }^{10}$. A study from south Karnataka among rural children aged $6-15$ years reported a prevalence of $10.5 \%{ }^{11}$. Another study from Bangalore revealed that the prevalence of asthma in children less than 18 years has increased steadily from $9 \%$ in 1979 to $29.5 \%$ in $1999^{5}$. In Tamil Nadu, data from Chennai published in 2002 showed that the prevalence of diagnosed asthma was $5 \%$ in children below 12 years of age ${ }^{6}$. Our data is comparable to this study and has confirmed the notion that the prevalence of asthma is higher in children in south India than previously thought. According to the background papers for the National commission on macroeconomics and health of the Government of India ( $\mathrm{NCMH})$, the prevalence rate of chronic asthma in children $<15$ years is 861 per 100,000 in urban areas and 1024 per 100,000 persons in rural areas. In the western world, USA reported figures of $9.1 \%$ in 2007 and the UK, around 20\%. ISSAC Phase 1 study reported 1 year prevalence rates of 4.1 to $32.1 \%$, among 6-7 year olds, with Australia, Brazil and Costa Rica having higher rates and India, Iran and Malaysia having lower rates. For the 13-14 year olds, similar figures ranged from 2.1 to $4.4 \%$ in China, Indonesia and Russia, while in Australia, New Zealand and UK it was 29.1 to $32.2 \%$. The low figures from India and China may be erroneous since very few representative nationwide studies have been done in these countries. More large scale studies are required in India to get a clearer picture regarding the overall prevalence and to document if the increase in prevalence is only in selected areas. Higher prevalence of asthma observed may be correlated with demographic changes in the city such as increase in the number of industries, density of population, and the number of automobiles.

\section{Parental history and asthma}

Many studies have found an association between asthma in children and family history of atopy, allergy or asthma in one or both parents ${ }^{12}$. Positive family history is one of the major criteria included in the asthma predictive index that is used to identify children with increased risk of developing asthma $^{13}$. Burke et al reviewed 33 population based studies and have found out that family history of asthma was consistently identified as a risk factor for asthma ${ }^{14}$. A recent study from south Karnataka reported a linear association with increasing age and family history of asthma ${ }^{11}$. Our study also showed this association in children of both age groups. This association could be either due to genetic factors or a shared environment. Studies in different countries have attempted to separate the relative contribution of genetic and environmental factors to the development of asthma ${ }^{15}$. Estimates of heritability (the proportion of phenotypic variance attributed to genetic factor) have ranged from $36 \%$ to $79 \%$, with the highest value coming from studies that had a comprehensive phenotypic assessment of asthma ${ }^{15}$.

\section{Food allergy and asthma}

Food allergy is a proven risk factor in asthma and can increase morbidity in asthmatic children ${ }^{16}$. Presence of food allergy is shown to be associated with increased risk of life threatening asthma ${ }^{17}$. Among 5-10 year old children in our study, while $22.7 \%$ of children with reported food allergy had asthma, only $8.1 \%$ without reported food allergy had asthma. In the 10-15 year age group, similar figures were 
$12.8 \%$ and $5.8 \%$. The association of food allergy with asthma in children aged 5-10 years was 2.36 times more than that of children without having food allergy. Since this is a questionnaire based study, this may be an overestimation of the association between food allergy and asthma. Data reported in our study are food allergies as perceived by the parents and not those scientifically proven. Studies report that while $25 \%$ people believe that they are allergic to some foods, only $4 \%-8 \%$ of children and $2 \%$ of adults have diagnosed food allergies. Foods which were found to be commonly associated with asthma are fish, shellfish, peanuts, other nuts, tomatoes, wheat, eggs, soya and chocolate $^{18,19}$. In India, while a study in Lucknow showed that fruit and vegetables were protective against asthma, a study from Bangalore concluded that fruits were a risk factor for asthma ${ }^{20}$. There is an urgent need for more studies in India to obtain clarity in this area.

\section{Television viewing and asthma}

Many studies have reported a strong association between higher duration of television viewing and asthma. Sheriff et al have documented that there is an association between television viewing in early childhood and subsequent prevalence of asthma ${ }^{21}$. Corba et al reported that watching TV more than 5 hours and a salty diet independently increase the risk of asthma in children aged $6-7$ years ${ }^{22}$. Also children glued to television for longer hours have increased exposure to indoor allergens ${ }^{23}$. Arvaniti $\mathrm{F}$ et al have documented an association between salty snack eating, television/video gaming and asthma in children aged 10-12 years ${ }^{24}$. Obesity has also been documented to be a risk factor for asthma. Our study has shown an association between television viewing for more than two hours and asthma among children aged 5-10 years. In our study, physical exercise was not significantly associated with asthma in the $11-15$ years age group. However, we observed an association between lack of exercise and asthma in univariate analysis in the age group 5-10 years, which has been reported in an earlier study. Overall, it seems likely that the association between TV watching and asthma is a result of multiple factors- obesity, lack of physical activity, excessive snacking and persistent exposure to indoor antigens. In our study, unhealthy eating habits like consumption of junk foods, carbonated drinks and red meat were not found to be significantly associated with presence of asthma. This could be due to the fact that these practices were not very common in the population studied due to cultural reasons.

\section{Low birth weight and asthma}

Our results showed that low birth weight (LBW) had a significant association with asthma in children aged 5-10 years but not in the age group of 11-15 years. In the 1970 British Cohort Study, low birth weight was associated with asthma at 5 years but not after 16 years. Other studies have also reported a high prevalence of asthma among children born $\mathrm{LBW}^{25}$. The reason could be multifactorial such as prematurity, invasive lung ventilation during neonatal period and recurrent respiratory illness during early childhood $^{26,27,28}$. It was earlier thought that LBW was more common in families living in an unhealthy environment making them prone to wheezing. But, a recent study concluded that even after excluding the effects of shared environment and genetic factors, there is a negative correlation between birth weight and asthma ${ }^{29}$.

\section{Environmental factors and asthma}

Among the indoor allergens, our findings have shown that usage of pillows made of wool, foam or synthetic material was more prevalent among 11 to 15 year old children with asthma, whereas cotton pillows acted as protective factor against asthma. This is similar to study conducted in China 30. There is strong evidence in literature that pillows and other bedding can contain millions of dust mites and other allergens that cause asthma symptoms ${ }^{31,32}$. In our study, poor ventilation was significantly associated with asthma among the children aged 11-15 years. Absence of windows in living rooms has already been considered as a significant risk factor associated with asthma ${ }^{33}$. Inadequate ventilation in homes may lead to increased dampness, which in turn facilitates growth of fungus and moulds which can induce asthma symptoms. Poor ventilation can also predispose to viral infection of the respiratory tract.

\section{Limitations and Strength of the study}

This study has some limitations. First, this is a school based study and hence not a truly representative of the general population. Second, since this is a questionnaire based study and there may be differences in comprehension of questions by the parents. Our study has several strengths. A validated ISSAC questionnaire was used to estimate the prevalence of asthma. Another strength of this study is that numerous variables included among risk factors allowing us to examine the independent effects of diverse risk factors. The final survey was conducted on $86 \%$ of the initial sample size, making this a fairly representative study.

\section{What this study adds}

The prevalence of asthma in children varies in different areas of India. Genetic susceptibility is an important predisposing influence. However, there are many factors like excessive television viewing, low birth weight, poor ventilation in homes and exposure to food or aero allergens which are preventable predisposing factors.

\section{Directions for research}

Asthma is a large economic burden on the country. Multi centric community based studies are required to demarcate areas of high prevalence, identify important predisposing environmental influences and devise region specific preventive strategies to reduce risk of asthma.

\section{Conclusions}

Our data suggest that there is a relatively high prevalence of asthma among school children in Coimbatore. The main risk factor among school going children of age 5-15 years is parental history of asthma. While factors such as longer duration of television viewing, low birth weight and food 
allergy are additional risk factors for children aged 5-10 years, poor ventilation and use of pillows made up of woollen or foam or synthetic material are the risk factors in 11-15 years old children. Recognition the risk factors will help parents, medical personnel and health planners device preventive and early intervention programs to reduce the burden of asthma in the community. More large community based surveys with the interviewer directly collecting information from parents and children can through more light on this obscure area.

\section{Conflict of Interests}

The authors do not have any conflict of interest arising from the study.

\section{Acknowledgement}

The authors are thankful to Dr. S. Ramalingam, Principal, PSGIMS\&R for permitting us to do the study, and to Dr. Thomas V Chacko, Professor \& Head of the Department of Community Medicine, PSGIMS\&R for providing the necessary support and facilities for doing this study. We are also thankful to Dr. Y. S. Sivan, Associate Professor, and Mr. K.V. Nanjappan, Health Educator, Department of Community Medicine, and Dr. Nithillavalli, Senior Resident, Department of Chest and Respiratory Diseases, PSGIMS\&R, Coimbatore for their encouragement and help in the successful completion of the study.

\section{Contribution of individual authors}

ACM designed the study, drafted the manuscript and revised it. PTG and RR collected the data, conducted the data analysis and drafted the first manuscript. SR and NS reviewed the literature and helped draft the manuscript. SK prepared the background material and helped design the study. JM designed the study and revised and prepared the final manuscript. All the authors approved the final document.

\section{References}

1. Peat JK, van den Berg RH, Green WF, Mellis CM, Leeder SR, Woolcock AJ. Changing prevalence of asthma in Australian children. BMJ 1994 ;308(6944):1591-6.

2. Worldwide variations in the prevalence of asthma symptoms: the International Study of Asthma and Allergies in Childhood (ISAAC). Eur Resp J1998; 12(2):315-35.

3. Weiss KB, Wagner DK. Changing pattern of asthma mortality: Identifying target population at risk. JAMA 1990; 264(13): 1683-7.

4. Worldwide variation in prevalence of symptoms of asthma, allergic rhinoconjunctivitis, and atopic eczema: ISAAC. The International Study of Asthma and Allergies in Childhood (ISAAC) Steering Committee. Lancet 1998; 351(9111): 1225-32.

5. Paramesh H. Epidemiology of asthma in India. Indian J Pediatr 2002; 69(4): 309-12.
6. Chakravarthy S, Singh RB, Swaminathan S, Venkatesan P. Prevalence of asthma in urban and rural children in Tamil Nadu. Natl Med J India 2002; 15(5): 260-3.

7. Gerrard JW, Vickers P, Gerrard CD. The familial incidence of allergy disease. Annals Allergy 1976; 36(1): 10-5.

8. Kumar L. Consensus guidelines on management of childhood asthma in India. Indian Pediatr 1999; 36(2): 15765.

9. Kumar P. Social Classification- Need for constant updating. Ind J Com Med 1993; 2: 60-1.

10. Shah JR, Amdekar YK, Mathur RS. Nationwide variation in prevalence of bronchial asthma. Ind J Med Scien 2000; 54(6) 213- 20.

11. Jain A, Vinod Bhat $H$, Acharya D. Prevalence of bronchial asthma in rural Indian children: a cross sectional study from south India. Indian J Pediatr 2010;77(1) :31-5.

12. Pokharel PK, Pokharel P, Bhatta NK, Pandey RM, Erkki K. Asthma symptomatics school children of Sonapur. Kathmandu Univ Med J (KUMJ) 2007 ;5(4):484-7.

13. Expert Panel Report 3 (EPR3): Guidelines for the diagnosis and management of asthma 2007. National Asthma Education and Prevention Program. [online] 2007 [cited 2011 October 27]. Available from: http://www.nhlbi.nih.gov/guidelines/asthma/asthgdln.htm.

14. Burke W, Fesinmeyer M, Reed K, Hampson L, Carlsten C. Family history as a predictor of asthma risk. Am J Prev Med $2003 ; 24(2): 160-9$.

15. Celedón JC, Soto-Quiros ME, Silverman EK, Hanson L, Weiss ST. Risk Factors for Childhood Asthma in Costa Rica. Chest 2001; 120(3):785-90.

16. Simpson AB, Glutting J, Yousef E. Food allergy and asthma morbidity in children. Pediatr Pulmonol 2007; 42(6):489-95.

17. Roberts G, Patel N, Levi-Schaffer, Habibi P, Lack G. Food allergy as a risk factor for life threatening asthma in childhood: a case-controlled study. J Allergy Clin Immunol 2003; 112(1): 168-74.

18. James JM, Bernhisel-Broadbent J, Sampson HA. Respiratory reactions provoked by double-blind food challenges in children. Am J Respir Crit Care Med 1994; 149(1): 59-64.

19. Novembre $E$, de Martino $M$, Vierucci $A$. Foods and respiratory allergy. J Allergy Clin Immunol 1988; 81 (5 Pt 2):1059-65.

20. Awasthi S, Kalra E, Roy S, Awasthi S. Prevalence and risk factors of asthma and wheeze in school going children in Lucknow, North India. Indian Pediatr 2004; 41(12): 1205-10.

21. Sheriff A, Maitra A, Ness AR, Mattocks C, Riddoch C, Reilly JJ, et al. Association of duration of television viewing in early childhood with the subsequent development of asthma. Thorax 2009; 64 (4): 321-5. 
22. Corbo GM, Forastiere F, De Sario M, Brunetti L, Bonci E, Bugiani $M$ et al. Wheeze and asthma in children: associations with body mass index, sports, television viewing and diet. Epidemiology 2008; 19(5): 747-55.

23. Gold DR, Wright R. Population disparities in asthma. Ann Rev Public Health 2005; 26:89-113.

24. Arvaniti F, Priftis KN, Papadimitriou A, Yiallouos $P$, Kapsokefalou M, Anthracopoulos MB et al. Salty-snack eating, television or video-game viewing, and asthma symptoms among 10 to 12 year old children: the PANACEA study. J Am Diet Assoc 2011; 111(2):251-7.

25. Brooks AM, Byrd RS, Weitzman M, Auinger P, McBride JT. Impact of low birth weight on early childhood asthma in the United States. Arch Pediatr Adolesc Med 2001 ;155(3):401-6.

26. Chan KN, Noble-Jamieson CM, Elliman A, Bryan EM, Aber VR, Silverman M. Lung function in children of low birth weight. Arch Dis Child 1989; 64(9):1284-93.

27. Mansell AL, Driscoll JM, James LS. Pulmonary follow up of moderately low birth weight infants with and without respiratory distress syndrome. J Pediatr 1987; 110(1):111-5.

28. Clarke JR, Reese A, Silverman M. Bronchial responsiveness and lung function in infants with lower respiratory illness over the first six months of life. Arch Dis Child 1992; 67(12):1454-8.

29. Villamor $E$, Iliadou A, Cnattingius $S$. Is the association between low birth weight and asthma independent of genetic and shared environmental factors? Am J Epidemiol 2009;169(11):1337-43.

30. Wong GW, Ko FW, Hui DS, Fok TF, Carr D, von Mutius E et al. Factors associated with difference in prevalence of asthma in children from three cities in China: multicenter epidemiological survey. BMJ 2004 ; 329 (7464):486.

31. Kemp TJ, Siebers RW, Fishwick D, O'Grady GB, Fitzharris $P$, Crane J. House dust mite allergen in pillows. BMJ 1996;313(7062):916.

32. Hallam C, Custovic A, Simpson B, Houghton N, Simpson A, Woodcock A. Mite allergens in feather and synthetic pillows. Allergy 1999;54(4):407-8.

33. Strachan DP, Careey IM. Home environment and severe asthma in adolescence: a population based case control study. BMJ 1995; 311(7012): 1053-6.

\begin{tabular}{|l|l|}
\hline \multicolumn{2}{|c|}{ Article Information } \\
\hline \multicolumn{2}{|c|}{ Article history } \\
\hline Received & 15 February 2012 \\
Received in revised form & 5 March 2012 \\
Accepted & 15 March 2012 \\
\hline
\end{tabular}

